\title{
EFFECT OF PROGRESSIVE MUSCLE RELAXATION ON ANXIETY IN CONGESTIVE HEART FAILURE PATIENTS
}

\author{
Sulastini' ${ }^{1}$, Henny Suzana Mediani'², Nita Fitria², Bambang Aditya Nugraha² \\ 1. STIKes Karsa Husada Garut, jl. Nusa Indah No. 24 Garut \\ 2. Universitas Padjadajaran, Jl. Raya Bandung Sumedang KM.21
}

\begin{abstract}
Anxiety is major psychological problem in congestive heart failure (CHF) patients. Anxiety leads to reduced quality of life. Anxiety can be treated using non phamacologic intervention. One of the interventions is progressive muscle relaxation (PMR). PMR is the most simple relaxation technique and possible to be applied in CHF patient. This study aimed to determine the effect of progressive muscle relaxation on anxiety IN CHF patients in dr. Slamet Garut hospital. This study used quasi-experimental design pretest and posttest with control group. Samples were selected using consecutive sampling technique (23 patients for each group). Hamilton Anxiety Rating Scale (HARS) was used to measured anxiety. Data were analyzed by Wilcoxon test and Mann-Whitney test. Analysis showed that there was a significant decrease in the mean anxiety score pre and post test both in the intervention and control group $(p=0.000)$ and a significant difference in mean anxiety score reduction between groups $(p=0.017)$ This study concluded that progressive muscle relaxation was effective to reduce anxiety levels in $\mathrm{CHF}$ patients. Nurses can apply progressive muscle relaxation as a complementary therapy to reduce anxiety in CHF patients.
\end{abstract}

Keywords: Anxiety, congestive heart failure, progressive muscle relaxation

\section{ABSTRAK}

Kecemasan merupakan salah satu permasalahan psikologis yang sering muncul pada pasien gagal jantung kongestif (GJK). Kecemasan dapat menyebabkan penurunan kualitas hidup pasien GJK. Kecemasan dapat ditangani melalui intervensi nonfamakologis, salah satunya adalah relaksasi otot progresif (ROP). ROP merupakan salah satu teknik relaksasi yang cukup mudah dan sederhana, serta sangat mungkin untuk diaplikasikan pada pasien GJK. Penelitian ini bertujuan untuk mengetahui pengaruh relaksasi otot progresif terhadap tingkat kecemasan pasien GJK di ruang rawat inap RSU dr. Slamet Garut. Penelitian ini menggunakan desain quasi experimental dengan rancangan pretest and posttest with control group. Teknik sampel yang digunakan adalah consecutive sampling. Sampel sebanyak 46 pasien, 23 pasien untuk kelompok intervensi dan 23 pasien untuk kelompok kontrol. Kecemasan diukur menggunakan Hamilton Anxiety Rating Scale (HARS). Data dianalisis dengan Wilcoxon dan Mann-Whitney test. Hasil analisa data menunjukan bahwa terdapat penurunan rerata skor kecemasan yang signifikan antara pre dan post baik pada kelompok intervensi dan kelompok kontrol $(p=0.000)$ dan terdapat perbedaan rerata penurunan skor kecemasan yang signifikan di antara kelompok $(p=0.017)$. Hasil penelitian dapat disimpulkan bahwa relaksasi otot progresif dapat menurunkan tingkat kecemasan pada pasien GJK. Perawat diharapkan dapat menerapakan relaksasi otot progresif di rumah sakit sebagai salah satu terapi komplementer non farmakologis untuk mengatasi kecemasan.

Kata Kunci: Kecemasan, gagal jantung kongestif, relaksasi otot progresif 


\section{BACKGROUND}

Congestive Heart Failure (CHF) is the inability of the heart to pump adequate blood to meet the tissues need for oxygen and nutrients (Smeltzer, Bare, Hinkle, \& Cheever, 2010). According to World Health Organization (WHO) (2013), approximately 17.3 million people died from cardiovascular disease in 2008 and it is estimated that over 23 million people every year will die from cardiovascular disorders. Indonesia Basic Health Research (RISKESDAS, 2007) showed that heart disease remains a major cause of deaths of patients in hospital in Indonesia. It is estimated that West Java province has the highest number of patients with symptoms of heart failure as many as 96,487 people (0.3\%).

In 2014, the prevalence of CHF in Garut was 1,460 cases and the number of patient hospitalized due to CHF from January 2015 to February 2016 was 1,680 cases. The prevalence of CHF in Garut district has increased as many as 220 cases since 2014 (Pemkab Garut, 2016).

Some clinical manifestations of patients with CHF are dyspnea, tachycardia, fatigue, activity intolerance, fluid retention, decreased arterial blood oxygen levels, pulmonary edema, peripheral edema, inconvenience, and disruption of sleep patterns (Yancy et al., 2013). Beside physical problems, psychological problems are also experienced by patients with CHF. Some predisposing factors which lead to anxiety are weak physical condition, prolonged treatment, recurrent hospital admission, prognosis of the disease, and cost of the treatment (Fitriyani, 2015). Those situations can cause psychological problems such as stress, anxiety, helplessness (powerlessness), fear and depression (Polikandrioti et al., 2015).

Anxiety is a pathological state characterized by feelings of fear accompanied by somatic sign of the autonomic nervous system hyperactivity (Kapplan, Saddock, \& Grebb, 2010). Anxiety can lead to decreased quality of life. Schweitzer (2007) found that anxiety is one of the causes of non-compliance behavior in CHF patients
There are some nursing interventions to overcome anxiety, for example cognitive therapy, behavioral therapy, thought stopping, CBT (Cognitive Behaviour Therapy), logotherapy, SEFT (Spiritual Emotional Freedom Technique), and relaxation techniques (Hofmann, 2008). Relaxation is a form of mind body therapy (Black \& Hawks, 2009). Progressive muscle relaxation is one of the simplest relaxation techniques and has been used widely. According to Richmond (2004) progressive muscle relaxation is a relaxation procedure by contracting and relaxing the muscles.

Some researches on progressive muscle relaxation have been carried out in patients with heart problems and hypertension and other chronic diseases who experience anxiety. Progressive muscle relaxation was proven to overcome anxiety in breast cancer patients undergoing chemotherapy, and kidney failure patients undergoing hemodialysis. Hui, Wan, Chan and Yung (2006) conducted a study to evaluate the effectiveness of progressive muscle relaxation and qigong in the rehabilitation program of patients with heart problems and hypertension. Results of the study showed that progressive muscle relaxation and qigong were effective in reducing blood pressure, but qigong was more effective to reduce anxiety compared to progressive muscle relaxation. Charalambous, Giannakopoulou, Bozas, and Paikousis (2015) also conducted a research using the RCT method to investigate the effects of guided imagery and progressive muscle relaxation on anxiety and depression in patients with prostate cancer and breast cancer while having chemotherapy. Results showed that progressive muscle relaxation and guided imagery were significantly effective to reduce level of anxiety and depression as shown by lowered cortisol levels.

Progressive muscle relaxation can overcome anxiety through the following mechanism. Contraction of skeletal muscle fibers leads to the sensation of muscular tension as a result of complex interaction of nervous and muscular system (Conrad \& Roth, 2007). 
Movements in progressive muscle relaxation stimulate the limbic system in the hypothalamus to release Corticotrophin Realizing Factor (CRF). CRF then stimulates production of endorphin and Pro Opioid Melano Cortin (POMC) by pituitary, which increase the production of encephalin by adrenal medulla. Later, it affect mood and give a feeling of relaxation (Black \& Hawks, (2009). Relaxed feeling can accelerate the healing process and improve the quality of life of patients with congestive heart failure.

Untreated anxiety in patients with CHF leads to re-hospitalization, decreased quality of life, depression, and addiction to anti-anxiety medication. Nurses have to provide nursing care to meet bio-psychosocio-spiritual needs of patients. Nursing care is not only aimed to treat the physical problems, but also psychological problems, such as stress and anxiety. The purpose of this study was to determine the effect of progressive muscle relaxation on anxiety in patients with congestive heart failure functional.

\section{METHODS}

This study used a quasiexperimental design pretest and posttest with control group. Ethical approval has been gained from Medical Faculty of Padjadjaran University No. 554/UN6.C1.3.2/KEPK/PN/2016. Samples were selected using consecutive sampling method, with inclusion criteria as follow: hospitalized patients of grade I and II CHF (NYHA Functional Class) experiencing anxiety, fully conscious (compos mentis), are willing to participate from beginning to end. A total of 46 respondents which divided into two groups (23 respondents each) were involved in this study. Respondents were patients treated at $\mathrm{dr}$. Slamet Garut on internal medicine ward with CHF. Hamilton Anxiety Rating Scale (HARS) was used to measure anxiety. HARS has been proven to be a valid and reliable instrument to measure anxiety ( 0.77 and 0.81 for validity and reliability respectively) (Shear et al., 2001). This instrument consists of 14 groups of symptoms with 5 point scales description, no symptoms (score 0), light symptoms (score 1), moderate symptoms (score 2), serious symptoms (score 3) and very serious symptoms (score 4).

PMR was given to intervention group two times a day, in the morning and afternoon for 3 days by researcher. PMR consisted of few stages: first was concentration, then patient focused on muscle contraction and relaxation. After that, they practiced the movement with semi-Fowler's position or lying in bed with his head on a pillow. Every muscle groups were contracted for 5-10 seconds and relaxed for 10-20 seconds. There are about 14 movements in total. Respondents learned the movements in 3 sessions to help them remembering the movements. Respondents in control group did not receive PMR. Data were analyzed by Wilcoxon test and Mann-Whitney test.

\section{RESULTS}

Table 1. Demographic characteristics of respondents $(n=46)$

\begin{tabular}{lcc}
\hline & $\begin{array}{c}\text { Interventio } \\
\mathbf{n}(\mathbf{n = 2 3}) \\
\mathbf{f}(\%)\end{array}$ & $\begin{array}{c}\text { Control } \\
(\mathbf{n = 2 3}) \\
\mathbf{f}(\%)\end{array}$ \\
\hline Age & $1(4.3)$ & $1(4.3)$ \\
$26-35$ & $6(26.1)$ & $6(26.1)$ \\
$36-45$ & $6(26.1)$ & $5(21.7)$ \\
$46-55$ & $8(34.8)$ & $9(39.2)$ \\
$56-65$ & $2(8.7)$ & $2(8.7)$ \\
$\geq 66$ & & \\
Sex & & \\
Male & $6(26.1)$ & $7(30.4)$ \\
$\quad$ Female & $17(73.9)$ & $16(69.6)$ \\
IIIness duration & & \\
$\quad<6$ months & $8(34.8)$ & $7(30.4)$ \\
$>6$ months & $15(65.2)$ & $16(69.6)$ \\
\hline
\end{tabular}

Characteristics of respondents are described in table 1. Table 1 shows that age, sex and illness duration of respondents in both intervention and control groups were relatively similar. Most respondents in both groups were age between 56-65 years old. Majority of respondents in both groups were female and, had suffered $\mathrm{CHF}$ more than 6 months.

Table 2. Mean Anxiety Score $(n=46)$

\begin{tabular}{lccc}
\hline & Pre test & Post test & p-value \\
\hline Intervention & 23,13 & 19,00 & 0,000 \\
Control & 23,26 & 21,52 & 0,000 \\
\hline
\end{tabular}


Mean anxiety score at pre and post-test of both groups are shown in table 2. Table 2 shows that mean anxiety score in intervention group at pre and post-test were 23.13 and 19.00 respectively. Meanwhile, in control group, mean anxiety score in the pre-test and post-test were 23.26 and 21.52, respectively. Wilcoxon test in intervention group showed $p$-value 0.000 ( $p<0.05$ ) which meant that there was a significant difference in mean anxiety score before and after progressive muscle relaxation interventions. Similar result was also found in control group. There was a significant difference in mean anxiety score at pre and posttest ( $p$-value 0.000).

Table 3. Mean Deviation of Anxiety Score $(n=46)$

\begin{tabular}{lcc}
\hline & $\begin{array}{c}\text { Deviation } \\
\text { (Mean, SD) }\end{array}$ & p-value \\
\hline Intervention & $4.13(4.65)$ & 0.017 \\
Control & $1.74(4.03)$ & \\
\hline
\end{tabular}

Table 3 shows mean deviation of anxiety score in both groups. Analysis using Mann Whitney test showed that there was a significant difference in mean deviation of anxiety score between groups $(p=0.017)$. It means that progressive muscle relaxation was significantly effective to reduce anxiety compare to standard therapy.

\section{DISCUSSION}

This study found that many of respondents aged between 56-65 years old. This finding was supported by research conducted by Debasree, Smita, Nitin, and James (2013) among CHF patients in India. They found that anxiety was more likely experienced by patients aged 61 years old. Yancy et al. (2013) found that the incidence of $\mathrm{CHF}$ was higher in elderly because of the degenerative process. There are several factors why elderly are more susceptible to congestive heart failure disease. Response to beta-adrenergic stimulation due to age results in decreased heart rate and contractility. Anxiety is also often experienced by elderly with other chronic diseases such as kidney failure (Patimah, Suryani, \& Nuraeni, 2015).
This study found that the majority of patients were female. In general, men have a higher risk of heart failure than women because women have estrogen hormones which affect the metabolism of fat and cholesterol. Research by $\mathrm{He}$ et al. in America (2001) found that male had risk of heart failure 1.24 times higher than women. Hormonal factor also affect stress levels in women as they tend to have unstable hormone which result in unstable emotion (Mc Sweeney, Pettey, Lefler \& Heo, 2012).

In this study, about two third of respondents have suffered from CHF more than 6 months. Anxiety is often found in patients with chronic diseases such as heart failure. However, previous study found that anxiety was not related to the duration of the illness (Serafini et al., 2010).

Anxiety experienced by individuals could be influenced by several factors such as age, experience, selfconcept, education level, economic level and family support (Stuart \& Sunden, 2006). Haworth et al. (2005) in their study found that factors affecting anxiety in patients with CHF were age, gender, severity of disease, complications of other diseases such as diabetes, and also lack of social support.

Finding of this study showed that anxiety of respondents in intervention group were decreased after given progressive muscle relaxation. This finding was in line with research conducted by Chen et al. (2009) which found that anxiety levels of patients with schizophrenia was decline after given intervention of progressive muscle relaxation. Herizchi et al. (2012) also pointed out that there was a decrease in the level of anxiety in patients undergoing chemotherapy after received intervention progressive muscle relaxation for 1 month.

Progressive muscle relaxation is one of complementary therapies used to reduce anxiety and provide comfort (Snyder, Pestka \& Bly, 2006). Progressive muscle relaxation reduces anxiety through the following mechanism. First, muscle is contracted, and then stimulus will be delivered to the muscles via afferent nerve 
pathways. Contraction of skeletal muscle fibers will produce tension sensation. After that, muscle is relaxed. Relaxation is the elongation of the muscle fibers which can eliminate the sensation of tension. These techniques are applied to all major muscle groups. Progressive muscle relaxation allows individual to feel the sensation of tension and relaxation systematically (Mc Guigan and Lehrer, 2005).

In this study, progressive muscle relaxation was effective to reduce anxiety among patients with CHF. Progressive muscle relaxation has some benefits, including reducing muscle tension, increasing blood flow to the brain and increasing production of endorphins and encephalin (Snyder \& Lindquist, 2006).

Progressive muscle relaxation could overcome anxiety by contracting and relaxing some muscle groups. These techniques will stimulate the limbic system in hypothalamus to release Corticotrophin Releasing Factor (CRF). Then, CRF will stimulate the pituitary to increase production endorphin and Pro Opioid Melano Cortin (POMC). These hormones will improve encephalin production by the adrenal medulla that will affect the mood and give a feeling of relaxation. Endorphin is formed by polypeptide hormone containing 30 units of amino acids that bind opiate receptors in the brain. This hormone acts like morphine, even it is said that 200 times more effective than morphine. Endorphin is able to induce a feeling of euphoria, happy, comfortable, create tranquility and improve mood ((Black and Hawks, 2009).

The limitation of this study is that researchers not use tools to measure the degree of contraction and relaxation accurately during progressive muscle intervention due to its unavailability. Researchers only encouraged patients to contract the muscle as strong as possible to the patient's tolerance limits and relax it as much as possible.

\section{CONCLUSION}

Progressive muscle relaxation was effective to decrease anxiety among congestive heart failure. This study could be used as a reference for a manager or ward leader for preparing nursing care plans and developing standard operating procedures. For nurses, especially medical surgical nurses, this study provides evidence to apply progressive muscle relaxation as an intervention to reduce anxiety among coronary heart failure patients. In addition, nurses are also expected to explore knowledge and skills in carrying out progressive muscle relaxation training techniques

\section{REFERENCES}

Black, J. M., \& Hawks, J. K. (2009). Medical surgical nursing: Clinical management for positive outcomes, volume ii, $7^{\text {th }}$ edition. Elsevier's Health Sciences Right Department: Philadelphia.

Charalambous, A., Giannakopoulou, M., Bozas, E., \& Paikousis, L. (2015). A randomized controlled trial for the effectiveness of progressive muscle relaxation and guided imagery as anxiety reducing interventions in breast and prostate cancer patients undergoing chemotherapy. Evidence-Based Complementary \& Alternative Medicine (Ecam), 2015110 10p. doi:10.1155/2015/270876.

Chen, W., Chu, H., Lu, R., Chou, Y., Chen, C., Chang, Y., \& Chou, K. (2009). Efficacy of progressive muscle relaxation training in reducing anxiety in patients with acute schizophrenia. Journal of Clinical Nursing, 18(15), 2187-2196. doi:10.1111/j.13652702.2008.02773. $\mathrm{x}$

Conrad, A. \& Roth, T. W. (2007). Muscle relaxation therapy for anxiety disorders: it works but how?. Journal of Anxiety Disorder,. 21, 243264.ACCF/AHA Guideline for the Management of Heart Failure.

Debasree, D., Smita, K., Nitin, K., \& James, G. (2013). Depression and anxiety in heart failure patients in a South Indian population: a pilot study. Asian Journal of Biomedical 
and Pharmaceutical Sciences, 3(17), 65-70.

Easton, K., Coventry, P., Lovell, K., Lesley-Anne, C., \& Christi, D. (2016). Prevalence and measurement of anxiety in samples of patients with heart failure metaanalysis. Journal of Cardiovascular Nursing, 31(4), pp 367Y379. DOI: 10.1097/JCN.0000000000000265.

Fitriyani, R. (2015). Hubungan tingkat kecemasan dengan kualitas tidur pasien congestive heart failure (CHF) di ruang ICU RS PKU Muhammadyah Sruweng. Jurnal IImiah Kesehatan Keperawatan, 11(1).

Haworth, E. J., Cook, E., Moniz, Clark, A. L., Wang, M., Waddington, R., \& Cleland, J. G. F. (2005). Prevalence and predictors of anxiety and depression in a sample of chronic heart failure patients with left ventricular systolic dysfunction. The European Journal of Heart Failure. www.elsevier.com/locate/heafai.

He, J., Ogden, L. G., Bazzano, L. A., Vupputuri, S., Loria, C., \& Whelton, P. K. (2001). Risk factors for congestive heart failure in US men and women: NHANES epidemiologic follow-up study. Arch Intern Med, 161(7), 996-1002. doi:10.1001/ archinte.161.7.996.

Herizchi, S., Asvadi, I., Piri, I., Golchin, M., Shabanlui, R., \& Sanaat, Z. (2012). Efficacy of progressive muscle relaxation training on anxiety, depression and quality of life in cancer patients undergoing chemotherapy at Tabriz hematology and oncology research center. Middle East Journal of Cancer, 3(1), 9-13.

Hofmann, S. G. (2008). The efficacy of cognitive behavioral therapy: A Review of Meta-analyses. NIHPA
Author Manuscripts, 36(5): 427-440. http://circ.ahajournals.org/.

Hui, Wan, Chan, Yung. (2006). An evaluation of two behavioral rehabilitation programs, qigong versus progressive relaxation, in improving the quality of life in cardiac patients. The Journal of Alternative and Complementary Medicine, 12(4), 373-378.

Kapplan, H. I., Saddock, B. J., Grabbs, J. A. (2010). Buku Ajar Psikiatri, Edisi 2. Jakarta: EGC.

Mc Sweeney, J., Pettey, C., Lefler, L., \& Heo, S. (2012). Disparities in heart failure and other cardiovascular diseases among women. Womens Health (Lond Engl), 8(4): 473-485. doi: 10.2217/whe.12.22.

McGuigan, F. J., \& Lehrer, M. P. (2007). Progressive relaxation: Origin, principles, and clinical application. Diakses pada tanggal 20 Juli 2016 dari: www.bodypsychyoga.com.

Patimah, I., Suryani., \& Nuraeni, A. (2015). Pengaruh relaksasi dzikir terhadap tingkat kecemasan pasien gagal ginjal kronis yang menjalani hemodialisa. Jurnal Keperawatan Padjadjaran, 3(1).

Pemkab Garut (2016). Diakses pada tanggal 5 Maret 2016. http://www.garutkab.go.id/pub/static menu/detail/sosbud demografi.

Polikandrioti, M., Goudevenos, J., Michalis, L. K., Koutelekos, J., Kyristi, H., Tzialas, D., \& Elisaf, M. (2015). Factors associated with depression and anxiety of hospitalized patients with heart failure. Hellenic Journal of Cardiology; 56(1): 26-35.

Richmond, R. L. (2004). A guide to psychology and its practice. Diakses pada tanggal 3 Maret 2016 dari http://www.guidetopsychology.com/p rogressive muscle relaxation.htm. 
RISKESDAS. (2007). Laporan Nasional Riset Kesehatan Dasar. Di ambil dari www.riskesdas.litbang.depkes.go.id di akses pada tanggal 20 Februari 2016.

Schweitzer, R, D., Head, K., \& Dwyer, J. W. (2007). Psychological factors and treatment adherence behavior in patients with chronic heart failure. Journal of Cardiovascular Nursing 22(1), 76-83.

Serafini, G., Pompili, M., Innamorati, M., Lacorossi, G., Cuomo, I., Della Vista, M., Lester, D., De Biase, L., Girardi, P., Tatarelli, R. (2010). The Impact of anxiety, depression, and suicidality on quality of life and functional status of patients with congestive heart failure and hypertension. Prim Care Companion $J$ Clin Psychiatry. doi: 10.4088/PCC.09m00916gry.

Shear, K., Bilt, J., Vander., D, Paola, R., Lydiard, B., Michael, W., Linda, C, \& Jenna, W. (2001). Reliability and validity of a structured interview guide for the Hamilton Anxiety Rating Scale (SIGH-A). Depression and Anxiety 13:166-178.

Smeltzer, S. C., Bare, B. G., Hinkle, J. L., \& Cheever, K. H. (2010). Brunner \& Suddarth textbook of medicalsurgical nursing. Philadelphia: Lippincott Williams \& Wilkins.

Snyder, M \& Lindquist, R. (2006). Complementary/alternative terapies in nursing (fifth edition). New York: Springer Publishing Company.

Stuart \& Sundeen. (2006). Principles and practice of psychiatric nursing. St. Louis: Mosby.

World Health Organization. (2013). World health statistic. $\mathrm{Di}$ ambil dari http://search.who.int/search di akses pada tanggal 20 Februari 2016.

Yancy, W. C., Jessup, M., Chair, V., Bozkurt, B., Butler, J \& Casey, D, E.
(2013). ACCF/AHA Guideline for the Management of Heart Failure. http://circ.ahajournals.org/. Di akses tanggal 15 februari 2016.

Yohannes, A., Willgoss, T., Baldwin, R., \& Connolly, M. (2010). Depression and anxiety in chronic heart failure and chronic obstructive pulmonary disease: prevalence, relevance, clinical implications and management principles. International Journal of Geriatric Psychiatry, 25(12), 1209-1221 13p. doi:10.1002/ gps.2463 